\title{
Analysis of postoperative course after pancreatic resections - experience of one centre
}

\section{Analiza przebiegu pooperacyjnego po resekcjach trzustki - doświadczenie jednego ośrodka}

\author{
Stanisław Głuszek ${ }^{1,2,3}$, Marta Kot ${ }^{1}$, Jarosław Matykiewicz ${ }^{2,3}$, Łukasz Nawacki, ${ }^{1,3}$ I Iwona Wawrzycka ${ }^{1,3}$, \\ Monika Kozłowska-Geller ${ }^{3}$, Magdalena Kołomańska1,4, Jakub Kuchinka ${ }^{4}$, Paweł Zieliński \\ Martyna Głuszek-Osuch ${ }^{5}$, Jacek Haduch², Jacek Bicki ${ }^{1,3}$, Dorota Kozieł \\ ${ }^{1}$ Clinic of General, Oncological and Endocrine Surgery, Regional Polyclinical Hospital, Kielce, Poland \\ Head of the Department and Clinic: Prof. Stanisław Głuszek MD, PhD \\ ${ }^{2}$ Clinic of Oncological Surgery, Kielce Region Oncology Centre, Kielce, Poland \\ Head of the Clinic: Jacek Haduch MD, Consultant: Prof. Stanisław Głuszek MD, PhD \\ ${ }^{3}$ Department of Surgery and Surgical Nursing with Laboratory for Research and Laboratory for Genetics, Faculty of Medicine \\ and Health Sciences, Jan Kochanowski University, Kielce, Poland \\ Head of the Department: Prof. Stanisław Głuszek MD, PhD \\ ${ }^{4}$ Department of Human Anatomy, Faculty of Medicine and Health Sciences, Jan Kochanowski University, Kielce, Poland \\ Head of the Department: Prof. JKU Tadeusz Kuder \\ ${ }^{5}$ Laboratory of Medical Psychology and Education, Institute of Public Health, Faculty of Medicine and Health Science, Jan Kochanowski \\ University, Kielce, Poland \\ Head of the Laboratory: Aldona Kopik PhD
}

Medical Studies/Studia Medyczne 2018; 34 (4): 317-324

DOI: https://doi.org/10.5114/ms.2018.80948

Key words: pancreatic cancer, pancreatic resection, postoperative complications, pancreatic fistula.

Słowa kluczowe: nowotwory trzustki, resekcja trzustki, powikłania pooperacyjne, przetoka trzustkowa.

\begin{abstract}
Introduction: Pancreatic resections belong to the most difficult surgical procedures and are still burdened with a high percentage of complications.

Aim of the research: To analyse both the medical records of patients qualified for surgical treatment and the postoperative course after procedures of radical resection of the pancreas, with consideration of the most severe complications.

Material and methods: Postoperative courses were analysed in 100 patients who had undergone pancreatic resection.

Results: The most frequent indications for pancreatic resection were: cancer of the ampulla of Vater (30), pancreatic cancer (24), inflammatory tumours (16), and benign cystic tumours (12). In 8 cases, pancreatic resection (distal) was an element of the surgery due to advanced gastric cancer, while the remaining were: lymphoma (2), neuroendocrine tumour (2), adenoma with high-grade dysplasia involving the ampulla of Vater (2), GIST (1), IPMN (1), fibromatosis (1), and injury (1). The most frequently performed surgery was partial resection of the organ (73: proximal resection -35 , distal resection - 38). Total pancreatectomy was performed in 20 patients, and in 3 patients the surgery was limited to resection of the tumour. The dominant postoperative complications were pancreatic fistulas (9\%) and haemorrhages (5\%). Only one case of fistula was surgically treated. Surgical intervention was necessary in all cases of haemorrhagic complications (in 2 patients - several times). During the postoperative period 5 deaths were registered (5\%).

Conclusions: Pancreatic surgery remains a very difficult discipline, which requires not only excellent surgical technique, but also skill in the management of postoperative complications.
\end{abstract}

\section{Streszczenie}

Wprowadzenie: Resekcje trzustki należą do najtrudniejszych procedur chirurgicznych i nadal są obarczone dużym odsetkiem powikłań.

Cel pracy: Analiza danych medycznych chorych zakwalifikowanych do leczenia operacyjnego oraz przebiegu pooperacyjnego po radykalnych zabiegach resekcyjnych trzustki u 100 chorych, z uwzględnieniem najcięższych powikłań.

Materiał i metody: Retrospektywnej analizie klinicznej poddano przebiegi pooperacyjne u 100 chorych po zabiegach resekcyjnych trzustki. 
Wyniki: Najczęściej wskazaniami do resekcji trzustki były: rak brodawki Vatera (30), trzustki (24), guzy zapalne (16), łagodne guzy torbielowate (12). W 8 przypadkach resekcja trzustki (dystalna) była elementem operacji z powodu zaawansowanego raka żołądka. Pozostałe wskazania to: chłoniak (2), guz neuroendokrynny (2), gruczolak z dysplazją dużego stopnia brodawki Vatera (2), GIST (1), IPMN (1), fibromatoza (1), uraz (1). Najczęściej wykonywaną operacją było częściowe wycięcie narządu (73: resekcja proksymalna - 35, resekcja dystalna - 38). U 20 chorych wykonano całkowitą pankreatektomię; a u 3 chorych operacja ograniczyła się do wycięcia guza. Najczęstszymi powikłaniami pooperacyjnymi były przetoki trzustkowe (9\%) oraz krwotoki (5\%). Tylko 1 przypadek przetoki był leczony operacyjnie. We wszystkich przypadkach powikłań krwotocznych konieczna była interwencja chirurgiczna (u 2 chorych - kilkakrotna). W okresie pooperacyjnym zanotowano 5 zgonów (5\%).

Wnioski: Chirurgia trzustki jest nadal dyscypliną bardzo trudną, wymagającą nie tylko doskonałej techniki operacyjnej, lecz także umiejętności leczenia powikłań pooperacyjnych.

\section{Introduction}

The indications for pancreatic resection are most often malignant cancers of the pancreas and hepatoduodenal bulb, including the ampulla of Vater, as well as benign neoplastic changes, intraductal papillary mucinous neoplasms (IPMN), and inflammatory changes (chronic pancreatitis). Pancreatic cancer, as a complex clinical problem, in a considerable number of cases is a fatal disease, due to late diagnosis and difficult treatment $[1,2]$. In 2014, morbidity due to pancreatic cancer worldwide was estimated at 337,872 cases. In the same year, 330,391 patients died [3, 4]. In 2010 in Poland, 3254 cases were registered in the National Cancer Registry, with an increase in the number of cases in the ninth decade of life. In addition, the risk of contracting pancreatic cancer is related with tobacco smoking $[5,6]$, Afro-American ethnicity [6], aged over 55 years $[6,7]$, male gender $[6]$, obesity $[6,8]$, and concomitance of IPMN and diabetes [8, 9]. Moreover, the risk of pancreatic cancer is increased by: family history of pancreatic cancer, chronic pancreatitis, hereditary pancreatitis, Peutz-Jeghers syndrome, familial atypical multiple mole melanoma, familial cancer syndromes, familial adenomatous polyposis (FAP), hereditary breast and ovarian cancer syndrome with BRCA1 and BRCA2 mutations [10, 11], and other mutations that are still under research.

Thus, while seeking the causes for the development of pancreatic cancer, the above-mentioned factors are considered (tobacco smoking, life style, low physical activity, obesity), and most often genetic factors, diabetes, chronic pancreatitis, as well as peptic ulcer and reflux disease, and drugs taken for other diseases. Concerning the problem of the overuse of proton pump inhibitors (PPI), Peng et al. [2] found that in patients using PPI for $<30$ days the risk of pancreatic cancer was: $\mathrm{OR}=0.89$ (95\% CI: 0.62-1.27), whereas in those using PPI for $\geq 150$ days it was 2.22 (95\% CI: 1.68-2.94) [2]. The researchers concluded that the risk of pancreatic cancer was related with administration of PPI in patients with gastric ulcer or gastro-oesophageal reflux disease.

Apart from primary prophylaxis, which remains unsatisfactory, an early diagnosis of pancreatic cancer creates the greatest chance for the patient. Despite the fact that, according to the guidelines in effect, a cytological/histopathological diagnosis is not necessary before surgical treatment, the application of neoadjuvant or palliative chemotherapy requires the cytological/histopathological confirmation of cancer. It is recommended that the EUS be performed with fine needle aspiration biopsy (EUS with FNA).

The outcomes of surgical treatment are best in patients with tumours less than $2 \mathrm{~cm}$ in size, without spread beyond the pancreatic capsule and without metastasis to the lymph nodes, described as an early stage of the disease (grades I and II A). At this stage of the disease, the prognosis is decisively better. Therefore, determination of the risk groups based on scientific data, determination of the specific biomarkers, and improved advanced imaging of the pancreas may allow, in the future, detection of the disease at its early stage and enable the performance of curative resection [12]. Long-term survivals are possible. The mean 5-year survival in patients who had undergone resection is on the level of $18-24 \%[1,3,4,13]$. Despite the progress in surgery and modification of surgical techniques, complications still remain a very important problem after pancreatic resection, ranging from $3 \%$ to $45 \%$. An important issue also concerns complications after surgical treatment, in the form of pancreatic fistulas, the frequency of which is from $11 \%$ to $19 \%$, in centres that are considered as 'high volume' $[14,15]$.

Apart from aetiological and strictly surgical problems (postoperative course, complications), the presence of the disease is also related with psychological difficulties in patients. Pancreatic cancer, as a disease with poor prognosis and high biological aggressiveness, is associated with psychological symptoms, such as depression and anxiety [16]. Patients ill with pancreatic cancer experience persistent levels of depression prior to surgery and for 6 months afterwards, accompanied by subjective symptoms such as pain and gastrointestinal symptoms. Pancreatic resections performed for other indications also present similar problems during the postoperative period. The premise of this study was an analysis of the problems related with the complexity of the stage of qualification for resection, the surgery itself, and postoperative course. 


\section{Aim of the research}

The aim of the study was analysis of medical records of patients qualified for surgical treatment, and analysis of the postoperative course after the procedures of radical pancreatic resection in 100 patients, with consideration of the most severe complications.

\section{Material and methods}

Medical records of 100 patients qualified for surgical treatment and postoperative course after procedures of radical pancreatic resection were analysed. The analysis included: 1) indications for resection, degree of clinical advancement TNM, (pancreatic cancer, cancer of the ampulla of Vater, other neoplasms, inflammatory changes, injuries); 2) postoperative course - complications: pancreatico-enteric fistulas or pancreatic fistulas in the case of peripheral resection, haemorrhages, surgical site infections, death; and 3) analysis of management in the case of complications and assessment of the degree of advancement pTNM.

\section{Results}

In the analysed group there were 46 females; mean age -59.6 years (30-79), and 53 males - mean age -57.6 years (20-73). The most frequent indications for pancreatic resection were: cancer of ampulla of Vater (30), pancreas (24), inflammatory tumours (16), benign cystic tumours (12); in 8 cases pancreatic resection (distal) was a component of surgery due to advanced gastric cancer; while the remaining were: lymphoma (2), neuroendocrine tumour (2), adenoma with high-grade dysplasia involving the ampulla of Vater (2), GIST (1), IPMN (1), fibromatosis (1), and injury (1). The most frequently performed surgery was a partial resection of the organ (73), proximal resection (35), distal resection (38), total pancreatectomy (20), in 3 patients the surgery was limited to the resection of the tumour. The dominant postoperative complications were pancreatic fistulas (9\%) and haemorrhages (5\%). Only 1 case of the fistula was surgically treated. Surgical intervention was necessary in all cases of haemorrhagic complications (in 2 patients several times). During the postoperative period 5 deaths were registered (5\%). The average length of stay in the ward was 19 days (7-67).

TNM classification was applied only with respect to the patients in whom pancreatic cancer was ultimately diagnosed (Tables 1-5).

In the analysed group, after pancreaticoduodenectomy, entero-pancreatic anastomosis of the ductto-mucosa type were most frequently performed, or side-to-end anastomosis of full cross-section of the pancreas to the intestine, more rarely entero-pancreatic anastomosis was performed by intussusception, or pancreatic-gastric anastomosis. The dominant postoperative complications were pancreatic fistulas
Table 1. Pancreatic cancer in general $(n=37)$

\begin{tabular}{|lccc|}
\hline TNM & No. of females & No. of males & Total \\
O & 1 & 0 & 1 \\
IA & 3 & 2 & 5 \\
IB & 5 & 4 & 9 \\
IIA & 2 & 4 & 6 \\
IIB & 4 & 11 & 15 \\
III & 0 & 0 & 0 \\
IV & 1 & 0 & 1 \\
\hline
\end{tabular}

Table 2. Division of the group of patients according to indications for surgery

\begin{tabular}{|lc|}
\hline Indications & No. \\
Cancer of the ampulla of Vater & 30 \\
Pancreatic cancer & 24 \\
Pancreatic inflammatory tumours & 16 \\
Benign cystic tumours & 12 \\
Advanced gastric cancer & 8 \\
Lymphoma & 2 \\
Neuroendocrine tumour & 2 \\
Adenoma with high-grade dysplasia involving & 2 \\
the ampulla of Vater & \\
GIST & 1 \\
IPNM & 1 \\
Fibromatosis & 1 \\
Injury & 1 \\
Total & 100 \\
\hline
\end{tabular}

Table 3. Division of the group of patients according to the type of surgery

\begin{tabular}{|lc|}
\hline Type of surgery & No. \\
Distal pancreatic resection & 38 \\
Proximal pancreatic resection & 35 \\
Total pancreatectomy & 20 \\
Tumourectomy & 3 \\
Total & 100 \\
\hline
\end{tabular}

(9\%) and haemorrhages (5\%). Bleeding in two patients, was related with entero-pancreatic anastomosis, and in 2 patients after left resection. In $1 / 4$ of the patients, somatostatin was prophylactically used after the resection; in all patients, somatostatin was applied as an element of treatment. Deep surgical side infection was observed in all patients with entero-pancreatic anastomosis and bleeding (10\%). 
Table 4. Death during postoperative period

\begin{tabular}{|c|c|c|c|c|c|c|c|}
\hline Patient & Gender & $\begin{array}{c}\text { Age } \\
\text { [years] }\end{array}$ & $\begin{array}{l}\text { Indication } \\
\text { for surgery }\end{array}$ & TNM & $\begin{array}{l}\text { Type of } \\
\text { surgery }\end{array}$ & Type of complication & $\begin{array}{l}\text { Final } \\
\text { outcome }\end{array}$ \\
\hline 1 & M & 56 & CCP & T3N1M0 & PDL-T & $\begin{array}{l}\text { Acute renal failure, haemorrhage } \\
\text { into the peritoneal cavity }\end{array}$ & Death \\
\hline 2 & M & 46 & APV & T3N1M0 & PDL-T & Myocardial infarction & Death \\
\hline 3 & M & 62 & APV & T2N1M0 & PD & $\begin{array}{l}\text { Haemorrhage into the peritoneal } \\
\text { cavity, haemorrhage into the lumen } \\
\text { of gastrointestinal tract }\end{array}$ & Death \\
\hline 4 & M & 59 & APV & T2NOMO & PDL-T & $\begin{array}{l}\text { Entero-pancreatic anastomotic } \\
\text { fistula, recurrent haemorrhages into } \\
\text { the peritoneal cavity }\end{array}$ & Death \\
\hline 5 & M & 56 & APV & T2NOMO & PD & $\begin{array}{c}\text { Three anastomotic leakages, } \\
\text { eventration, haemorrhage from } \\
\text { surgical wound, multiple organ } \\
\text { dysfunction }\end{array}$ & Death \\
\hline
\end{tabular}

Table 5. Fistulas after procedures of pancreatic resection

\begin{tabular}{|c|c|c|c|c|c|c|c|}
\hline Patient & Gender & $\begin{array}{c}\text { Age } \\
\text { [years] }\end{array}$ & $\begin{array}{l}\text { Indication } \\
\text { for surgery }\end{array}$ & TNM & $\begin{array}{l}\text { Type of } \\
\text { surgery }\end{array}$ & Type of complication & $\begin{array}{l}\text { Final } \\
\text { outcome }\end{array}$ \\
\hline 1 & M & 47 & ATPI & T2N1MO & PDL-T & $\begin{array}{c}\text { Enteropancreatic anastomotic } \\
\text { fistula, internal bleeding due to } \\
\text { damage to the splenic capsule, } \\
\text { adhesive obstruction }\end{array}$ & $\begin{array}{l}\text { Discharged } \\
\text { home }\end{array}$ \\
\hline 2 & M & 59 & APV & T2NOMO & PDL-T & $\begin{array}{c}\text { Enteropancreatic anastomotic } \\
\text { fistula with recurrent } \\
\text { haemorrhaging into the } \\
\text { peritoneal cavity }\end{array}$ & Death \\
\hline 3 & $\mathrm{~F}$ & 64 & ATV & - & & $\begin{array}{l}\text { Enteropancreatic anastomotic } \\
\text { fistula }\end{array}$ & $\begin{array}{l}\text { Discharged } \\
\text { home }\end{array}$ \\
\hline 4 & $\mathrm{~F}$ & 69 & SCT & - & PDL-T & $\begin{array}{l}\text { Biliary fistula, bleeding into the } \\
\text { lumen of gastrointestinal tract } \\
\text { from the site of pancreatic- } \\
\text { gastric anastomosis }\end{array}$ & $\begin{array}{l}\text { Discharged } \\
\text { home }\end{array}$ \\
\hline 5 & M & 59 & CPV & T1NOMO & PD & $\begin{array}{c}\text { Anastomotic leakages: } \\
\text { enteropancreatic, biliary- } \\
\text { enteric, and gastro-intestinal, } \\
\text { eventration, intra-abdominal } \\
\text { abscess }\end{array}$ & Death \\
\hline 6 & M & 53 & $\begin{array}{l}\text { Inflammatory } \\
\text { pancreatic } \\
\text { tumour in the } \\
\text { course of CP }\end{array}$ & - & $C R$ & $\begin{array}{l}\text { Chronic postoperative } \\
\text { pancreatic fistula. }\end{array}$ & $\begin{array}{l}\text { Discharged } \\
\text { home }\end{array}$ \\
\hline 7 & M & 20 & $\begin{array}{l}\text { Multiple organ } \\
\text { dysfunction - } \\
\text { rupture of the } \\
\text { pancreas }\end{array}$ & - & $C R$ & $\begin{array}{l}\text { Dehiscence of intestinal } \\
\text { anastomosis, recurrent } \\
\text { haemorrhaging into the lumen } \\
\text { of gastrointestinal tract }\end{array}$ & $\begin{array}{l}\text { Discharged } \\
\text { home }\end{array}$ \\
\hline 8 & $\mathrm{~F}$ & 62 & $\begin{array}{l}\text { Inflammatory } \\
\text { tumour in the tail } \\
\text { of the pancreas }\end{array}$ & - & $C R$ & Pancreatic fistula & $\begin{array}{l}\text { Discharged } \\
\text { home }\end{array}$ \\
\hline 9 & $\mathrm{~F}$ & 47 & $\begin{array}{l}\text { Benign cystic } \\
\text { tumour in the tail } \\
\text { of the pancreas }\end{array}$ & - & CR & Pancreatic fistula & $\begin{array}{l}\text { Discharged } \\
\text { home }\end{array}$ \\
\hline
\end{tabular}

$M$ - male, $F$-female, CCP - carcinoma capitis pancreatic, APV - adenocarcinoma papillae Vateri, ATPI - adenocarcinoma tabulo-papillare invasivum, ATV - adenoma tabulo-vilosum cum focis dysplasiae maioris gradus, SCT - serous cystic tumour, CPV - carcinoma papillae Vateri, $C P$ - chronic pancreatitis, PDL-T - pancreaticoduodenectomy Longmire-Traverso, $P D$ - pancreaticoduodenectomy - Whipple procedure, $C R$-circumferential resection of the pancreas with splenectomy. 
Deaths during postoperative period -5 :

1) male, 56 years, ca capitis pancreatis, T3N1M0, pancreaticoduodenectomy using the Longmire-Traverso technique; acute renal failure, bleeding into the peritoneal cavity? - death on the third postoperative day.

2) male, 46 years, adenocarcinoma papillae Vateri, T3N1M0, pancreaticoduodenectomy using the Longmire-Traverso technique; myocardial infarction - death on the second postoperative day.

3) male, 62 years, adenocarcinoma papillae Vateri, T2N1M0, pancreaticoduodenectomy - Whipple procedure; intraperitoneal haemorrhage, haemorrhage into the lumen of the gastrointestinal tract death on the $10^{\text {th }}$ postoperative day.

4) male, 59 years, adenocarcinoma papillae Vateri G1, T2N0M0, pancreaticoduodenectomy using the Longmire-Traverso technique; recurrent haemorrhages into the peritoneal cavity in the course of entero-pancreatic anastomosis fistula; CA in the mechanism of ventricular fibrillation during the subsequent (third) laparotomy - death on the $23^{\text {rd }}$ day after the primary surgery.

5) male, 56 years, adenocarcinoma G2 papillae Vateri, T2N0M0, pancreaticoduodenectomy - Whipple procedure; three anastomotic leakages, eventration, haemorrhage from surgical wound, resurgery, multiple organ dysfunction - death on $33^{\text {rd }}$ day after primary surgery (on the first day after resurgery).

\section{Fistulas after pancreatic resection procedures}

Male, 47 years, unburdened, operated due to cancer of the of the ampulla of Vater (adenocarcinoma tabulo-papillare invasivum G1); pancreaticoduodenectomy using the Longmire-Traverso technique was performed; progression: T2N1M0; on the first day after surgery symptoms of internal haemorrhaging - operated on an ad hoc basis - injury of the splenic capsule observed; splenectomy performed; on subsequent days, symptoms of entero-pancreatic anastomosis were observed; conservative treatment was applied (somatostatin, TPN) on the $14^{\text {th }}$ day after surgery due to the symptoms of adhesive disease; further course - without complications; discharged on the $24^{\text {th }}$ day after primary surgery.

Male, 59 years, unburdened, operated on due to cancer of the ampulla of Vater (adenocarcinoma G1); pancreaticoduodenectomy using the LongmireTraverso technique was performed; progression: T2NOM0; entero-pancreatic anastomosis fistula with recurrent haemorrhages to the peritoneal cavity; for this reason had undergone three surgery three times: on the $14^{\text {th }}, 18^{\text {th }}$, and $23^{\text {rd }}$ day after primary surgery during the last relaparotomy CA in the mechanism of ventricular fibrillation and death.
Female, 64 years, unburdened, operated on due to cancer of the ampulla of Vater (adenoma tabulo-villosum cum focis dysplasiae maioris gradus); pancreaticgastric anastomosis fistula; conservative treatment (somatostatin, TPN); hospitalisation - 42 days.

Female, 69 years, unburdened, operated on due to benign cystic pancreatic head tumour (serous cystic tumour); pancreaticoduodenectomy using the Longmire-Traverso technique was performed; during postoperative period the symptoms of biliary fistula observed, and bleeding into the lumen of the gastrointestinal tract from the site of pancreatic-gastric anastomosis; conservative treatment, somatostatin, endoscopic intervention; hospitalisation - 44 days.

Male, 59 years, unburdened, operated on due to cancer of the ampulla of Vater (carcinoma papillae Vateri); pancreaticoduodenectomy - Whipple procedure was performed; progression: T1N0M0; during postoperative period the symptoms of leakage from enteropancreatic anastomosis, biliary-enteric anastomosis, and gastro-intestinal anastomosis; eventration; initially an intensive conservative treatment (TPN, targeted antibiotic therapy, active suction drainage); on $34^{\text {th }}$ day, due to arterial haemorrhage from the postoperative wound, operated on an ad hoc basis - bleeding vessel was punctured, multiple intra-abdominal abscesses evacuated, the remaining part of the pancreas (tail) removed, anastomotic leakages eliminated; new anastomoses performed: gastro-intestinal and biliary-enteric using the Roux loop; during the surgery - massive transfusion of PRBCs and FFP; patient's death on the next day $\left(35^{\text {th }}\right.$ day of hospitalisation).

Male, 53 years, unburdened, operated on due to inflammatory pancreatic tumour (in the course of $\mathrm{CP}$ ); circumferential pancreatic resection (body and tail) with splenectomy was performed; cross-section of the pancreas closed by single sutures; postoperative chronic pancreatic fistula - resurgery performed three and a half months after the first procedure - enteropancreatic anastomosis performed using the Roux route; postoperative course without complications.

Male, 20 years, unburdened, operated on due to multiple organ dysfunction (rupture of the pancreas, liver, spleen, contusion of the duodenum, injury to mesentery of the small and large intestine, retroperitoneal haematoma), circumferential pancreatic resection with splenectomy performed (among others); during postoperative period relaparotomy performed three times due to dehiscence of intestinal anastomosis and recurrent haemorrhages into the lumen of the gastrointestinal tract (endoscopic interventions ineffective); hospitalization - 28 days.

Female, 62 years, with diabetes, after previous surgery by Jurasz technique due to post-inflammatory pancreatic cyst; operated on due to inflammatory tumour of the pancreatic tail; during postoperative pe- 
riod a prolonged leakage of content from the site of pancreatic stump; conservative treatment; hospitalisation -8 days.

Female, 47 years, unburdened, operated on due to a benign cystic tumour of the pancreatic tail; circumferential pancreatic resection (body and tail) with splenectomy was performed; cross-section of the pancreas closed by single sutures; during postoperative period pancreatic fistula conservatively treated (somatostatin, percutaneous drainage of fluid collection in the postoperative lodge; hospitalisation - 30 days).

\section{Discussion}

Pancreatic resection procedures are performed for cancer indications and bring with them the risk of postoperative complications, even up to $50 \%$, and the risk of postoperative mortality remains within the range from 0 to more than a dozen per cent, according to the structure by age, indications for resection procedures, experience of the centre, degree of advancement of cancer, and the necessity for the resection of vessels in the analysed groups of patients. An important problem concerns complications after surgical treatment in the form of pancreatic fistulas, the frequency of which is $11-19 \%$, and postoperative mortality is within the range $3-5 \%$ in centres considered as 'high volume' $[14,15]$. Wiltberger et al. [17] retrospectively evaluated the effect of factors on postoperative complications and predictors of survival and morbidity. The records of 225 patients were analysed with malignant cancer of the hepato-duodenal bulb, i.e. pancreatic cancer (124-55.1\%), cancer of the distal part of the common bile duct $(55-24.4 \%)$, and duodenal bulb cancer (46-20.4\%). Complications were observed in $30.7 \%$ of patients, most frequently pancreatic fistulas occurred in bile duct cancer. Statistical analysis allowed determination of the risk factors of complications: male gender, BMI over $30 \mathrm{~kg} / \mathrm{m}^{2}$, resection $\mathrm{R} 1$, and low differentiation of tumour [17]. The most severe complications - pancreatic fistulas - are also discussed as a result of the proper surgical technique. Many authors of nonrandomised studies consider that the duct-to-mucosa method results in a lower number of pancreatic fistulas than invagination anastomosis; however, in observation studies the frequency of fistulas was as much as $20 \%$. Duct-to-mucosa anastomosis may be difficult in a soft, fragile, and fatty pancreas. Hence, in such situations, anastomosis using the invagination method is recommended [18]. Shrikhande et al. [15] elaborated the standpoint of the International Study Group of Pancreatic Surgery (ISGPS), based on 109 articles selected according to the above-described methodology from among 2221 studies preliminarily found in the PubMed database from the years 1995-2015. Analysis of these articles shows that contemporarily there is no technique that could eliminate the complication in the form of pancreatic fistula. Efforts undertaken to stan- dardise surgical techniques may decrease the frequency of fistulas; an experienced surgeon may use various techniques according to the intraoperative situation. None of the anastomosis techniques: pancreaticojejunostomy and pancreaticogastrostomy, duct-to-mucosa anastomosis, invagination method, and combined techniques show the superiority of one over the other. The benefits from the placement of the prosthesis in the pancreatic duct prior to enteropancreatic anastomosis have been unequivocally confirmed. The use of somatostatin analogues may considerably decrease morbidity after pancreatoduodenectomy, in selected situations, high risk, without decreasing mortality. It may be routinely applied in patients at high risk. Drainage of the peritoneal cavity should be avoided in cases of low risk of fistula, whereas with mediocre and high risk of fistula it is justifiable to use drainage of the peritoneal cavity.

A considerable postoperative morbidity is generally related with more aggressive cancers of the gastrointestinal tract. This relationship remains controversial in the case of pancreatic cancer. Sandini et al. [19] analysed the problem of whether severe complications after surgical resection exert any effect on long-term survival. The registers of all patients with pancreatic cancer, who had undergone surgery during the period 2007-2015, were reviewed. High morbidity was defined as 30-day complications of Grade 3 or higher, according to the Clavien-Dindo Classification. The patients who died within 90 days of surgery were excluded from the analysis of survival. From among 616 patients with pancreatic cancer, $81.7 \%$ had undergone pancreatoduodenectomy and $18.3 \%$ distal pancreatectomy. Severe complications occurred in 19.1\% of patients after pancreatoduodenectomy and 15.9\% of those after distal pancreatectomy. In patients who survived for $>90$ days, the probability of receiving adjuvant therapy was $43.9 \%$ if serious complications occurred, compared to $68.5 \%$ if these complications did not occur $(p<0.001)$, while those who received this therapy started treatment 10 days later than the patients without complications (median: 60 days (5072 ) vs. 50 days (41-61), $p=0.001)$. Severe complications deteriorated long-term survival after pancreatoduodenectomy (median: OS 26 months vs. 15 months; $p=0.008)$. The difference was also clear after distal pancreatectomy; however, it was statistically insignificant, probably due to the small size of the sample (median: OS 33 months vs. 18 months; $p=0.189$ ). In multivariate analysis of the outcomes of pancreatoduodenectomy, the major postoperative complications remained independently related with poorer survival (HR $=1.37$, 95\% CI: 1.01-1.86). The researchers sum up that severe surgical complications after pancreatic resection are related with poorer long-term survival in the case of pancreatic cancer. This effect is independent from the reception of adjuvant therapy [11, 20]. 
In the analysed group after pancreatoduodenectomy, duct-to-mucosa enteropancreatic anastomosis, or end-to-side anastomosis full cross-section of the pancreas to the intestine were most frequently performed, while enteropancreatic anastomosis using the intussusception method and pancreatic-gastric anastomosis were performed more rarely. The dominant postoperative complications were pancreatic fistulas (6\%) and haemorrhages (5\%); bleeding in 2 patients was related with enteropancreatic anastomosis, and in 2 patients after left-side resection. In approximately $1 / 4$ of patients, somatostatin was prophylactically applied after resection; in all patients with fistulas, Somatin was used as an element of treatment. Deep infection of the surgical site was observed in all patients with pancreatic-enteric fistulas and bleedings (10\%).

\section{Conclusions}

Analysis of our own experiences indicates that early outcomes of treatment after pancreatic resection are close to those obtained in centres with extensive experience in surgical treatment of pancreatic diseases.

\section{Conflict of interest}

The authors declare no conflict of interest.

\section{References}

1. Ryan DP, Hong TS, Bardeesy N. Pancreatic adenocarcinoma. N Engl J Med 2014; 371: 2140-1.

2. Peng YC, Lin CL, Hsu WY, Lu IT, Yeh HZ, Chang CS, $\mathrm{Kao} \mathrm{CH}$. Proton pump inhibitor use is associated with risk of pancreatic cancer: a nested case-control study. Dose Response 2018; 16: 1559325818803283.

3. Ilic M, Ilic I. Epidemiology of pancreatic cancer. World J Gastroenterol 2016; 22: 9694-705.

4. Takaori K, Bassi C, Biankin A, Brunner TB, Cataldo I, Campbell F, Cunningham D, Falconi M, Frampton AE, Furuse J, Giovannini M, Jackson R, Nakamura A, Nealon W, Neoptolemos JP, Real FX, Scarpa A, Sclafani F, Windsor JA, Yamaguchi K, Wolfgang C, Johnson $\mathrm{CD}$; IAP/EPC study group on the clinical managements of pancreatic cancer. International Association of Pancreatology (IAP)/European Pancreatic Club (EPC) consensus review of guidelines for the treatment of pancreatic cancer. Pancreatology 2016; 16: 14-27.

5. Lynch SM, Vrieling A, Lubin JH, Kraft P, Mendelsohn JB, Hartge P, Canzian F, Steplowski E, Arslan AA, Gross M, Helzlsouer K, Jacobs EJ, LaCroix A, Petersen G, Zheng W, Albanes D, Amundadottir L, Bingham SA, Boffetta P, Boutron-Ruault MC, Chanock SJ, Clipp S, Hoover RN, Jacobs K, Johnson KC, Kooperberg C, Luo J, Messina C, Palli D, Patel AV, Riboli E, Shu XO, Rodriguez Suarez L, Thomas G, Tjønneland A, Tobias GS, Tong E, Trichopoulos D, Virtamo J, Ye W, Yu K, Zeleniuch-Jacquette A, Bueno-de-Mesquita HB, Stolzenberg-Solomon RZ. Cigarette smoking and pancreatic cancer: a pooled analysis from the pancreatic cancer cohort consortium. Am J Epidemiol 2009; 170: 403-13.
6. Paez D, Labonte MJ, Lenz HJ. Pancreatic cancer: medical management (novel chemotherapeutics). Gastroenterol Clin North Am 2012; 41: 189-209.

7. Muncibi F, Paez DC, Matassi F, Carulli C, Nistri L, Innocenti M. Long term results of percutaneous fixation of proximal humerus fractures. Indian J Orthop 2012; 46: 664-7.

8. Magruder JT, Elahi D, Andersen DK. Diabetes and pancreatic cancer: chicken or egg? Pancreas 2011; 40: 339-51.

9. Canto MI, Harinck F, Hruban RH, Offerhaus GJ, Poley JW, Kamel I, Nio Y, Schulick RS, Bassi C, Kluijt I, Levy MJ, Chak A, Fockens P, Goggins M, Bruno M; International Cancer of Pancreas Screening (CAPS) Consortium. International Cancer of the Pancreas Screening (CAPS) Consortium summit on the management of patients with increased risk for familial pancreatic cancer. Gut 2013; 62: 339-47.

10. Klein AP. Genetic susceptibility to pancreatic cancer. Mol Carcinog 2012; 51: 14-24.

11. Głuszek S, Kozieł D. Determinacja genetyczna w raku trzustki. Medical Studies 2018; 34: 178-82.

12. Okano K, Suzuki Y. Strategies for early detection of resectable pancreatic cancer. World J Gastroenterol 2014; 20 : 11230-40.

13. Gluszek S, Kowalik A, Koziel D, Wawrzycka I, GluszekOsuch M, Matykiewicz J. CTRC gene polymorphism may increase pancreatic cancer risk - preliminary study. Pol Przegl Chir 2017; 89: 48-53.

14. Bassi C, Marchegiani G, Dervenis C, Sarr M, Abu Hilal M, Adham M, Allen P, Andersson R, Asbun HJ, Besselink MG, Conlon K, Del Chiaro M, Falconi M, FernandezCruz L, Fernandez-Del Castillo C, Fingerhut A, Friess H, Gouma DJ, Hackert T, Izbicki J, Lillemoe KD, Neoptolemos JP, Olah A, Schulick R, Shrikhande SV, Takada T, Takaori K, Traverso W, Vollmer CR, Wolfgang CL, Yeo CJ, Salvia R, Buchler M; International Study Group on Pancreatic Surgery (ISGPS). The 2016 update of the International Study Group (ISGPS) definition and grading of postoperative pancreatic fistula: 11 years after. Surgery 2017; 161: 584-91.

15. Shrikhande SV, Sivasanker M, Vollmer CM, Friess H, Besselink MG, Fingerhut A, Yeo CJ, Fernandez-delCastillo C, Dervenis C, Halloran C, Gouma DJ, Radenkovic D, Asbun HJ, Neoptolemos JP, Izbicki JR, Lillemoe KD, Conlon KC, Fernandez-Cruz L, Montorsi M, Bockhorn M, Adham M, Charnley R, Carter R, Hackert T, Hartwig W, Miao Y, Sarr M, Bassi C, Büchler MW; International Study Group of Pancreatic Surgery (ISGPS). Pancreatic anastomosis after pancreatoduodenectomy: a position statement by the International Study Group of Pancreatic Surgery (ISGPS). Surgery 2017; 161: 1221-34.

16. Shigemoto Y, Sone D, Maikusa N, Okamura N, Furumoto S, Kudo Y, Ogawa M, Takano H, Yokoi Y, Sakata M, Tsukamoto T, Kato K, Sato N, Matsuda H. Association of deposition of tau and amyloid-beta proteins with structural connectivity changes in cognitively normal older adults and Alzheimer's disease spectrum patients. Brain Behav 2018: e01145.

17. Wiltberger G, Krenzien F, Atanasov G, Hau HM, Schmelzle M, Bartels M, Benzing C. Pancreaticoduodenectomy for periampullary cancer: does the tumour entity influence perioperative morbidity and long-term outcome? Acta Chir Belg 2018; 118: 341-7. 
18. Marcus SG, Cohen H, Ranson JH. Optimal management of the pancreatic remnant after pancreaticoduodenectomy. Ann Surg 1995; 221: 635-45.

19. Sandini M, Honselmann KC, Birnbaum DJ, Gavazzi F, Chirica M, Wellner U, Guilbaud T, Bolm L, Angrisani M, Moutardier V, Cereda M, Girard É, Montorsi M, Keck T, Zerbi A, Gianotti L. Preoperative biliary stenting and major morbidity after pancreatoduodenectomy: does elapsed time matter? The FRAGERITA Study Group. Ann Surg 2018; 268: 808-14.

20. Sandini M, Ruscic KJ, Ferrone CR, Warshaw AL, Qadan M, Eikermann M, Lillemoe KD, Fernandez-Del Castillo C. Intraoperative dexamethasone decreases infectious complications after pancreaticoduodenectomy and is associated with long-term survival in pancreatic cancer. Ann Surg Oncol 2018; 25: 4020-6.

\section{Address for correspondence:}

Prof. Stanisław Głuszek MD, PhD

Department of Surgery

and Surgical Nursing

with Laboratory for Research

and Laboratory for Genetics

Faculty of Medicine and Health Sciences

Jan Kochanowski University

al. IX Wieków Kielc 19, 25-516 Kielce, Poland

Phone: +48 602715889

E-mail: sgluszek@wp.pl 